\title{
Performance Appraisal in the Public Sector in Niger
}

\author{
Harouna Saibou \\ School of Management, Wuhan University of Technology \\ Wuhan 430070, China \\ E-mail: harousaibou@yahoo.fr
}

Received: December 8, 2010 Accepted: December 30, 2010 doi:10.5539/ijbm.v6n6p263

\begin{abstract}
This paper examines the impact of performance appraisal in the public sector in Niger. Few administrative functions have attracted more attention on this and successfully resisted solution than employee evaluation. Since performance appraisal wasn't possible, then the personnel appraisal will be applied. When such hypocrisy occurs, civil service systems predicated on merit are undermined. The appraisal methodology applicable in the public sector in Niger is outdated and does not meet any criteria of objectivity, particularly measures its level of objectivity in the public sector in Niger.
\end{abstract}

Keywords: Performance appraisal, Public sector, Employee

\section{Introduction}

The public sector in most countries, small or big, are going through profound restructuring, trying to provide improved services while at the same time having to drastically downsize in the face of major fiscal constraints. "A significant element of such reforms in the public sector is the initiatives underway to reform public administration, to reinvent government to use a popular expression" (Mayne and Zapico-Goni, 1997). This process of reforming public administration is seen as necessary to meet the dual challenges of improved services with fewer resources. One of the most popular tools used for reform activities at present is Performance Appraisal Systems. "Strengthening government performance, improving the productivity, quality, timeliness, responsiveness, and effectiveness of public agencies; and programs are important to all, as beneficiaries of public service and as taxpayers" (Wholey, 2004) However, as Wholey has also suggested, a number of political, bureaucratic, and technical obstacles constrain government performance. Furthermore, Performance Appraisal (PA) is considered to be a particularly controversial management practice anywhere it is being practiced.

At this point it is essential to provide few definitions of what performance appraisal means in the reform context. With the growing amount of literature on performance appraisal, so has the definitions increased over the years. Therefore, the following definitions have been chosen which could be regarded as most relevant to this study.

Performance appraisal today is the assessment of an employee's job performance. It has two purposes:

- $\quad$ First appraisal serves an administrative purpose. It provides information for making salary, promotion, and layoff as well as providing documentation that can justify these decisions in court.

- Second, and perhaps more importantly, performance appraisal serves a development purpose. The information can be used to diagnose training needs, career planning, and the like. Feedback and coaching based on appraisal information provide the basis for improving day-to-day performance (Robins and Couter, 1999). Performance appraisal is defined as evaluating an employee's current or past performance relative to his or her performance standards. The appraisal process therefore involves:

- Setting work standards,

- Assessing the employee's actual performance relative to these standards,

- Providing feedback to the employee with the aim of motivating that person to eliminate performance deficiencies or to continue to perform above par (Dessler, 2000).

Performance appraisal is "the process of identifying, evaluating and developing the work performance of employees in the organization, so that the organizational goals and objectives are more effectively achieved, while at the same time benefiting employees in terms of recognition, receiving feedback, catering for work and offering career guidance" (Lansbury, 1988). 


\section{Literature review}

Although the use of performance appraisal has increased over the last few decades, the practice of formally evaluating employees has existed for centuries. As early as the third century A.D., Sin Yu, an early Chinese philosopher, criticized a biased rater employed by the Wei dynasty on the grounds that "the Imperial Rater of Nine Grades seldom rates men according to their merits but always according to his likes and dislikes" (Patten, 1997).

Systematic employee appraisal techniques came into prominence just after the end of World War I. During the war, Walter Dill Scott succeeded in persuading the United States Army to adopt 'man-to-man' rating system for evaluating military officers, although formal performance appraisal probably began in the United States in 1813 (Bellows and Estep, 1954) when army General Lewis Cass submitted to the War Department an evaluation of each of his men using such terms as 'a good-natured man' or 'knave despised by all' (Murphy and Cleveland, 1995).

Most of the merit rating plans from 1920 to the mid-1940s were of the rating scale type with factors, degrees and points. Indeed the analogy between a point plan of job evaluation and a rating scale plan of merit is very close. From the early 1950's greater interest was devoted in the performance appraisal of technical, professional and managerial personnel. However it has to be pointed out that with the changing nature on the emphasis, the terminology has also been changing over the years. Some of the other terms currently being used include personnel appraisal, personnel review, progress report, service rating, and performance evaluation and fitness report.

\section{Methodology}

The study was conducted in the Public Administration in Niger, one of a developing country in West Africa. The data used in this study was collected through the telephone contacts and questionnaires sent by E-mail in the form of file attached. After download and printing, employees responded to them and returned as attachment. Others information has collected by the Internet sites. The questionnaire took about ten minutes to complete. In all, 352 employees answered the self-administered questionnaire containing questions regarding appraisal, motivation, performance, and satisfaction.

\section{The form of appraisal}

The Appraisal methodology applicable in the public sector in Niger is outdated and does not meet any criteria of objectivity (Amblard and Abramovici, 1994; Boswell and Boudreau, 2002).

The different aspects evaluated using the appraisal forms are as follows:

- Timeliness in completing the work: The ability of an officer to perform a task within a specified time period. This ability is seen in terms of the efficiency to complete the task, plan and schedule the work according to the priorities.

- Knowledge of the job: The knowledge and experience acquired formally and informally that enable an officer to carry out the duties.

- Ability to organize: The ability to plan, arrange, distribute and mobilize the resources such as labor, equipment, information and finance to implement the tasks of the organization.

- Ability to make decisions: The ability to examine and consider all relevant factors and views and make right decisions within a specified time.

- $\quad$ Ability to solve problems: The ability to identify, consider various alternatives and solve problems.

- Communication skills: The ability to convey messages, views and instructions orally and in writing in terms of accuracy, effectiveness, clarity and courteousness.

- Leadership: The ability to supervise, manage and mobilize resources to implement the tasks of the organization. The ability in thinking and reasoning and having exemplary personal qualities.

\section{Purposes of conducting performance assessment}

In the Public Sector, the management needs to know how well employees had performed their job for the past twelve months.

The information is required by managers and supervisors to:

1. execute strategy in recruitment and selection, training and development, career planning, and compensation; 
2. give feedback to their subordinates on what are important so that they can take steps to improve their performance;

3. make managers and employees accountable for results and behaviors that bring positive results;

4. prepare performance improvement plans. Performance planning is an integral part of performance management.

The results need to show the level of quality of your people. You then can use this information to change your plans.

\section{Discussion and results}

The sample consisted of 352 employees in different offices in the Public Sector in Niger. The majority of respondents were men $(n=245$ or $69.6 \%)$. The number of respondents female is very low $(n=107$ or $30.3 \%)$. Most of the respondents males and females have an acceptable educational level $(n=318$ or $90.3 \%)$, the age group of the majority of respondents is $25-45$ years $(n=287$ or $81.5 \%)$. Almost the totality of respondents are permanently employed $(n=348$ or $98.8 \%)$.

\section{Insert table 1 here}

The results of this study indicate that employees of the Public sector in Niger where the research was conducted are not very satisfied with the system of appraisal.

About the indicators like "criteria" and "contribute to eliminate performance problems", the employees are disagreeing (60.51\% and $62.50 \%)$. It means that the criteria of evaluation of Human Resources in the public sector is not objective and constitute to a very old system of appraisal (Loi No 2007, 2007; Teboul, 1991).

About the motivation, the study show that the employees of the public sector in Niger are not very motivate by the appraisal (55.11\% of agree against $44.88 \%$ of disagree).

\section{Insert figure 1 here}

\section{Conclusion}

Everyone agrees today to consider that it is not possible to manage Human Resources in a mechanical way as the models of Taylor and Fayol. First, workforce demands have changed, and also the modernization of the administration requires most competitive category of personal. We found out through our study that the method of human resources appraisal in the public sector in Niger is old and does not meet any criteria of objectivity, causing frustration and demotivation. It is the duty of government to carry out some changes so as to develop tools for evaluation of modern human resources, capable of making the difference between the best and bad agents. Further studies are needed to enrich the system knowledge on performance appraisal and its impact on organizational performance in developing countries, such as Niger to measures its level and objectivity in the public sectors.

\section{Acknowledgements}

The author wish to thank Amadou Issoufou for providing his service and comments that substantially improved the article.

\section{References}

Amblard, H., \& Abramovici, Y.F. (1994). Management des ressources humaines, $3^{\text {eme }}$ Edition Seminaire de formation en gestion des ressources humaines, tenu a L'ENA de Niamey au Niger.

Bellows, R. M., \& Estep, M. F. (1954). Employment psychology: The interview. New York: Rinehart.

Boswell, W. R., \& Boudreau, J. W. (2002). Separating the developmental and evaluative performance appraisal uses. Journal of Business and Psychology, 16, 391-412.

Dessler, G. (2000). Human Resource Management. $8^{\text {th }}$ edition. New Jersey: Prentice Hall International, Inc

Lansbury, R. (1988). Performance management: A process approach. Human resource management, Australia, March.

Loi No 2007-26-du 23 juillet. (2007). Portant Statut General de la Fonction Publique de l'Etat du Niger.

Mayne, J., \& Zapico-Goni, E. (1997). "Effective performance monitoring: A necessary condition for public sector reform." In monitoring performance in the public sector, eds. Mayne, J., and Zapico-Goni, E. New Jersey: Transaction Publishers. 
Mohamed Faizal. (2005). Institutionalization of performance appraisal system: a case study of the Maldivian public service (Unpublished). University of Bergen, Norway.

Murphy, K.R., \& Cleveland, J.N. (1995). Understanding performance appraisal. Thousand Oaks: Sage Publications.

Patten, T.H. Jr. (1997). Pay: Employee compensation and incentive plans. London: Free Press.

Robins, S.P., \& Couter, M. (1999). Management. $6^{\text {th }}$ edition. New Jersey: Prentice-Hall.

Teboul, J. (1991). L'Entretien d'Evaluation : Comment le s'y comporter, comment le mener, Paris DUNNO.

Wholey, J.S. (2004). "Using evaluation to improve performance and support policy decisionmaking"; In M. C. Alkin, Evaluation roots, pp. 267-275, Thousand Oaks, CA: Sage.

Table 1. The appraisal survey in the public administration in Niger $(N=352)$

\begin{tabular}{|l|l|l|l|}
\hline Indicators & Agree & Disagree & Neither \\
\hline The Evaluation criteria are objective & $138(39.20 \%)$ & $213(60.51 \%)$ & $1(0.28 \%)$ \\
\hline Appraisal is an opportunity for advancement & $173(49.14 \%)$ & $179(50.85 \%)$ & $0(0.00 \%)$ \\
\hline Appraisal contribute to motivate employees & $194(55.11 \%)$ & $158(44.88 \%)$ & $0(0.00 \%)$ \\
\hline Contribute to eliminate performance problems & $127(36.07 \%)$ & $220(62.50 \%)$ & $5(1.42 \%)$ \\
\hline Employees receive the feedback & $178(50.56)$ & $174(49.43 \%)$ & $0(0.00 \%)$ \\
\hline
\end{tabular}

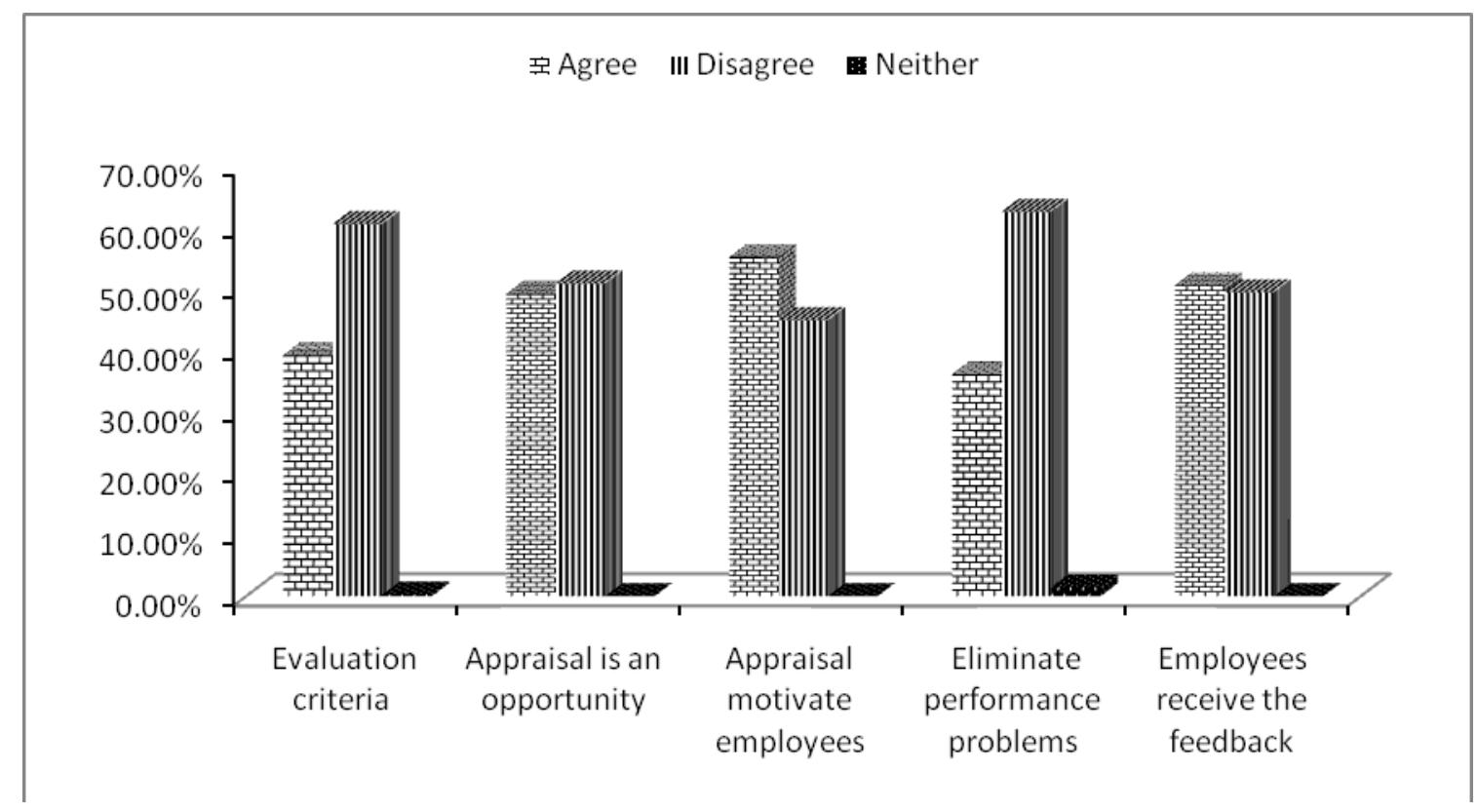

Figure 1. The appraisal survey in the public administration in Niger 